\title{
History Teachers' Competence in Implementing Authentic Assessment: A Case Study in a State Senior High School in Yogyakarta
}

\author{
Aman \\ Universitas Negeri Yogyakarta \\ Yogyakarta, Indonesia
}

\begin{abstract}
This study aimed to analyze the competence of history teachers in implementing the authentic assessment. The study used a descriptive qualitative method with a case study in a senior high school in Yogyakarta. The data sources of the study were history teacher, school principal, vice school principal of curriculum, and school supervisor. The collecting data techniques used were the interview, observation, and documentation. The validity of the data uses informant feedback and triangulation of method, data, and theory. The interactive model was applied to analyze the qualitative and quantitative data through some steps: data collection, data reduction, data presentation, and verification, or conclusion. The results showed that the assessment system in the school had followed the assessment guidance of Curriculum 2013 that related to spiritual, social, knowledge, and competence. The competence of history teachers in developing authentic assessment instruments has improved as viewed from the assessment instrument in line with primary and basic competence. The competence of history teacher competence was useful in implementing authentic assessment where there has been compatibility between the developed instrument and the assessment implementation. The competence of history teachers in processing the measurement result was also excellent, as proved by the whole analysis of measurement results to make assessment and evaluation. The study concluded that history teachers of the school subject have competence in implementing the authentic assessment.
\end{abstract}

Keywords: assessment instrument; authentic assessment; history teacher; teacher competence.

\section{Introduction}

Improving the quality of education is a process that is carried out dynamically and continuously in order to improve the quality of education and various factors associated with it, to achieve educational goals effectively and efficiently. The program to improve the quality of education is the achievement of 
substantive national education goals, which is manifested in intact competencies among students, including academic competence or intellectual capital, social competence or social capital, and moral competence or moral capital. These three essential capitals are the strength needed by every nation to be able to compete in the global era. One of the improvements in the quality of education is by increasing the quality of teachers or teaching staff, where an increase in the quality and ability of teachers also affects the improvement of student learning outcomes (Phillips, 2008 and Leigh, 2010). Effective educators play an essential role in facilitating and supporting reflective learning processes for student development (Richards \& Lockhart, 1996:98, and Celik, 2011).

In addition, according to The Australian Institute for Teaching and School Leadership (AITSL) (Celik, 2011), criteria for good teachers are teachers who have the ability to understand how students learn, understand how to teach, are able to design and implement effective teaching and learning processes, able to create and organize a sportive and safe learning environment, be able to assess, provide feedback and report student learning outcomes, engage in professional learning activities, and engage professionally with fellow teachers, parents or guardians and the community. Factors that affect the quality of education are teachers, students, school managers (principals, employees, and school committees), environment (parents, community, and schools), quality of learning, and curriculum. Based on previous research, the quality of education has not shown optimal quality, such as unequal access to education, lack of teachers in the 3T region, and the lack of educational facilities at various levels of education (Aman, 2015 and Nurhayati, Jayusman, \& Ahmad, 2018).

The principal as an instructional leader is one of the determining factors that can involve the school in realizing its vision, mission, and goals through various school programs. One of the main tasks of the principal is to improve the performance of teachers in schools. Many educational experts explain that improving school quality depends on efforts to develop school professionalism and teacher professionalism (Barth, 1981 and DuFour \& Barkey, 2005). The same thing was said by Mardapi (2013) that the efforts to improve the quality of education could be achieved through improving the quality of learning and the quality of the assessment system. Increasing the quality of learning carried out at various levels of education will be able to improve the quality of education. Efforts to improve the quality of education will take place well when supported by the competence and willingness of education managers to make continuous improvements in a better direction. Thus, continuous educational innovation in educational programs, including history learning programs, is a demand that must be implemented immediately.

The 2013 curriculum as a result of government policy is an answer to the urgency of the nation's need for curriculum changes. The purpose is that national education goals can be substantially achieved. Prihantoro (2015) added that the 2013 curriculum goals include developing demand, needs, and conditions related to aspects of society in achieving an education. The 2013 curriculum is also designed based on competency and is directed at achieving 
competency according to graduation competency standards. The learning system is based on active learning methods where students are expected to be able to conduct observing, questioning, associating, experimenting, and networking.

As for completeness of the teacher's handbook, students' books and assessment drafts that will be used are also available. Based on the concept of authentic assessment, the assessment draft has not yet reached all aspects, especially aspects of spiritual attitude. Frey \& Allen (2012) mentioned that authentic assessment includes the following indicators: 1) support for the passage of instructions in class; 2) varied activities in learning activities; 3) learning and teaching activities between teachers and students, and 4) local standards and values used. These indicators were commonly used in the assessment of social attitudes, knowledge, and skills of students, including in Indonesia's educational policy.

However, initial field data on the usage such type of indicators indicated obstacles in the authentic assessment mostly come in the form of practicality. The assessment instruments issued by the government so far have been impractical so that teachers find it difficult to assess students one by one in a variety of competencies. As a result, teachers only rely on paper-based assessments and pencil tests that can be carried out practically. The reality of the fields also shows the fact that learning activities and assessment instruments pay less attention to the learning flow of students. The teacher evaluates and uses teaching materials based on assumptions and estimates; even the teacher sometimes makes questions by taking questions that are already in the book. As the results of the research stated by Mulyana (2012) that teachers only make teaching materials and assessment of learning based on estimates of assumptions in learning. According to Falchikov \& Thomson (2008), the authentic assessment must support learning in general and be encouraged by students so that they can prepare student learning well (Rourke \& Coleman, 2011). According to Puckett \& Black (2000), authentic assessment sees teaching, learning, and assessment as ongoing, interrelated, influencing each other, and all happening at the same time (Azim \& Khan, 2012). Therefore, to improve student learning, we need to develop classroom assessments that provide high-quality information about student learning (Gulikers, Bastiaens, \& Kirschner, 2004).

According to Gronlund \& Linn (1990), the assessment is used as a guide by the teacher to group students into study groups, improve teaching methods, measure student readiness (attitude, mental and learning material), create instructions and selection to determine grade levels. Reynold, Livingstone, \& Wilson (2010) added that assessment is used as a guide in producing information that will guide educators in achieving better education. Retnawati, Hadi, \& Nugraha (2016) agree that assessment must be carried out to measure the achievement of student learning outcomes, and the assessment is known as authentic assessment. The criteria for good assessment instruments include valid, reliable, and practical criteria. Valid is interpreted as accuracy in measuring the ability of students. Reliability is interpreted as the degree of 
consistency of an instrument while practically interpreted as ease of use. If it meets all aspects and principles of assessment, it can be said to be an authentic assessment. An authentic assessment has been previously considered in many aspects of educational evaluation (Vu \& Dall'Alba, 2014 and Forsyth \& Evans, 2019).

The curriculum is the total effort of the school to influence students, both in the classroom and outside the school. This definition is refined into a plan to complete a set of learning opportunities to achieve learning objectives. Hasan (2008) describes the implementation of the curriculum as a process of a dimension, namely implementation, observation, or reality. The process by which the implementation has been designed in the form of documents and can have similarities or differences from documents.

Ornstein \& Hunkins (2009) added that a good curriculum implementation produces a meticulous plan which focuses on three factors, namely: the implementer, the program, and the curriculum process. Pinar \& Irwin (2005) stated that curriculum implementation could be understood from instrumental actions and situational practices. In instrumental actions, the implementation of programs can be viewed as a producer-consumer paradigm. Curriculum developers as producers produce a curriculum program for students and teachers who can be viewed as consumers. The implementation of the curriculum becomes a fundamental problem in how communication becomes effective in learning strategies. While for situational practice, it was based on learning experiences in class (Rusman, 2015).

According to General Medical Council (2010), a curriculum must set out the general, professional, and specialty-specific content to be mastered, including (a) the acquisition of knowledge, skills, and attitudes demonstrated through behaviours, and expertise (b) the recommendations on the sequencing of learning and experience should be provided, if appropriate (c) the general professional content should include a statement about how Good Medical Practice is to be addressed. Thus, matters relating to the curriculum must be based on learning outcomes that are general, professional, and that is specified in the ability to mastery of knowledge, skills, and attitudes. In addition, a curriculum must recommend learning experiences and professionalism (Chowthi-Williams, 2018 and Ayati, et al., 2019).

The curriculum does not only cover all planned activities but also events that occur under the supervision of the school. It includes formal and informal activities, mostly known as co-curricular and extracurricular. A course of study organized by the content to be covered and the activities used to cover it is called a curriculum. A curriculum for any course of study is described by its scope and sequence, the instructional events and learning experiences it encompasses, and the methods by which these events and experiences are delivered (Brown \& Green, 2016). A curriculum can be grouped into three parts: 1) planned curriculum which is written on the policy of education regulations with the aims and objectives of the learning curriculum (implemented by 
curriculum developers); 2) implemented or applicable curriculum where the interpretation of the curriculum and teaching and learning process carried out by the teacher (used by the teacher); and 3) achieved or assessed curriculum, where the implementation of learning is felt by students and assessed through the achievement of student learning outcomes (used by students) (Berkvens, Van den Akker, \& Brugman, 2014 and Khoza, 2016).

The 2013 Curriculum or Kurikulum 2013 was developed in the context of educational challenges in Indonesia with some improvements. Teacher-centred learning patterns were transformed into student-centered learning so that students must have choices on the material being studied to have the same competence. One-way learning patterns with the dominance of teacher-student interaction should become interactive learning where relationship teachers and students can be expanded to the community, natural environment, and resources, or other media. This curriculum also encourages teachers to bring students understanding multidisciplinary content to enhance their knowledge (Surya \& Aman, 2016). The curriculum was developed based on the theory of standards-based education and the theory of the competency-based curriculum. Education-based on standards stipulates the existence of national standards as a minimum quality of citizens broken down into content standards, process standards, graduate competency standards, teacher and education staff standards, facilities and infrastructure standards, management standards, financing standards, and education assessment standards (Hidayani, 2017 and Halek, 2019).

While the conception of authentic assessment, according to Azim and Khan (2012), assessment is a process that can help in the development of student learning and help teachers review or evaluate learning to improve student learning outcomes. The learning and teaching process and assessment are often regarded as an inseparable task where the curriculum is taught and then assessed. Assessment and evaluation are important in all sectors of education, where varied assessments must be used to produce more valid assessments of teacher and student abilities (Admiral et al., 2014). To improve student learning, we must develop classroom assessments that produce good information about student learning Description of assessment is more to the processes that facilitate student learning and not just to evaluate the learning and teaching process in the classroom (Azim \& Khan, 2012). Assessment can also be viewed as a process of gathering information to monitor progress and make educational decisions if needed. Assessment can include tests and methods such as observation, interviews, monitoring of behavior, and so forth (Huitt, Hummel, \& Kaeck, 2001).

Authentic assessment is a significant measurement of students' learning outcomes for the realm of attitudes, skills, and knowledge. The term assessment is a synonym of assessment, measurement, testing, or evaluation. The term authentic is a synonym of original, real, valid, or reliable. In everyday academic life, authentic valuation phrases and authentic judgments are often exchanged. However, the measurement phrase or authentic test is not commonly used. 
Newmann $(1997$, p. 361) describes authenticity as the key to intellectual quality, which is defined as the extent to which lessons, assessment assignments, or examples of student achievement that present knowledge through disciplined inquiry that has value in school success. Furthermore, Archbald \& Newmann (1988) added that in authentic assessments, students are required to be able to develop their own knowledge, develop relationships between the knowledge they already have and develop a deeper understanding of a topic, conduct learning activities, and express conclusions on the knowledge they have through elaboration communication (Palm, 2008).

Previous works in Indonesian contexts had identified some issues in relation to the implementation of authentic assessment. Some of these works focused on a variety of subjects such as Physics, Natural Sciences, English as a foreign language (EFL), and history. Rahayu, Maftukhin, \& Sriyono (2013) showed that students had a high achievement for Physics subjects in terms of attitude, process, and implementation when authentic assessment implemented in the classroom. Kurniawati \& Sukardiyono (2018) also indicated increasing students' performance in Natural Sciences subjects with the implementation of authentic assessment. Suastini, Marhaeni, \& Artini (2018) found that teachers in EFL faced some difficulties in implementing the authentic assessment. However, teachers in the study had a positive belief towards the assessment. Positive belief in authentic assessment also found Kardiana, Marhaeni, \& Ratminingsih (2019) among teachers in another school.

Aman's (2015) research on the readiness of vocational school history teachers in Yogyakarta Special Region in carrying out authentic assessments based on the 2013 curriculum, showed that history teachers were not ready to carry out authentic assessments. The teacher is not ready with a set of instruments that are so numerous and complicated that the instruments are not applicable. The research results are understandable, given that in the early days of the 2013 Curriculum implementation, the assessment instruments were very complicated and almost impossible for teachers to do. The instrument includes the assessment of spiritual skills, social, knowledge, and skills by demanding observation activities that are integrated with learning activities.

Likewise, Surya \& Aman's (2016) research of elementary school teachers in Pacitan showed that 90 percent of teachers had difficulty developing and applying authentic assessments caused by several factors, namely: the complexity of the instruments, understanding of assessment techniques, and the number of classes which is able to add to the lack of completeness in conducting an assessment. Therefore, teachers often do assessments at home after learning is carried out. This is undoubtedly the result of research that cannot portray the true abilities of students.

Based on the background and literature study above, this research aims to analyze the implementation of authentic assessment among history teachers in senior high schools in Yogyakarta. The focus of analysis would be in the current practice of teaching, the ability of history teachers in developing authentic 
assessment instruments, competency of History teachers in authentic assessment implementation, and ability of History teachers in processing the measurement results.

\section{Research Method}

This research uses a descriptive qualitative method with a case study research approach. With this research, it is expected that it can uncover various qualitative information with careful and meaningful description-analysis, which also does not reject quantitative information in the form of numbers. Data source sampling was conducted purposively, data collection techniques were triangulated, data analysis was inductive, and the research results emphasized more on meaning than generalization (Sugiyono, 2014, p. 15). Case studies are applied to this research, which requires holistic case studies, discusses more than one problem formulation, and seeks to understand the reality of the learning system and the ability of teachers to carry out authentic assessments.

This research was conducted in a state senior high school in Yogyakarta. The qualitative approach aims to find the meanings behind the facts carefully, not just narrative ideographic descriptions. This research is a case study research considering all two history teachers are the research subjects. The choice of cases in the subject school was based on its status as one of the favorite schools in Yogyakarta. It had also been a collaborative partner for many institutions conducting teaching practice and research. The school was known for its teachers' professionalism in carrying out learning activities. Data sources in this research were history teachers, school principals, deputy principals in the curriculum department, and school supervisors. Data were collected using interviews, observation, and documentation. The instrument used in addition to the researcher as a human instrument, is an interview guide, observation guide, and field notes. Data were validated using informant feedback techniques and triangulation of methods, data, and theory. The data were then analyzed using interactive analysis through the steps of data collection, data reduction, data presentation, and verification, or conclusion drawing.

\section{Results and Discussion}

The practice of history learning in the school subject showed the diversity of reflections ranging from the preparation of learning designs, methodologies, to evaluation. History teachers, in this case, have followed the learning procedures that were programmed in the implementation of learning activities. To fully understand the learning activities, including carrying out a comprehensive assessment, it was necessary to be serious in implementing it. An authentic assessment in the 2013 Curriculum underwent several policy changes both in terms of instruments, criteria, and implementation to value processing techniques. The last policy in 2016 added some novelty, for example, regarding the instrument's practice, criteria 1-100, to the value processing technique. In the 2013 Curriculum, basic competency derived from the core competencies (KI-1 and KI-2) for History subjects was eliminated. However, teachers were still 
required to develop instruments to assess spiritual and social attitudes, in addition to knowledge and skills in KI-3 and KI-4. Some ideal models based on 2016 authentic scoring system guidance, both regarding the instrument of spiritual attitude, social, knowledge, and skills assessment, could be presented as follow.

The first was the main instrument for assessing spiritual and social attitudes using student journals. The student journal was an instrument for recording the spiritual and social attitudes of students who stand out positively and negatively through the recording of numbers, times, student names, events, positive or negative, and follow-up on events or attitudes. The second was a component instrument for assessing students' knowledge in learning History. There were many kinds of assessment of knowledge: written test (true-false, multiple-choice, matching, entries, description); oral test (quiz and question and answer); assignments (tasks performed individually or in groups inside or outside school); and observation or portfolio techniques.

Skills assessment also used rubrics that are adjusted to the type of assessment bill as it concerns the following aspects. First performance/practice assessment that was conducted by observing student activities in History subject in the form of role-playing practices, presentations, and laboratory practices. Second project appraisal that investigates activities involving aspects of planning, implementation, and reporting of project results within a certain period. In learning History subjects, it could be in the form of research projects - third portfolios or records of learning outcomes with assessments that strengthen the progress and quality of student work. And fourth products, i.e., assessment of students' ability to make products, technology, and art. In History subjects, the product could be in the form of maps, mock-ups, papers, articles, research reports, and others.

Based on observations and interviews, it could be explained that the school subject has implemented the 2013 Curriculum. There are two History teachers at the time of research who were assisted by two students from the Department of History Education of a local university, in learning activities. The implementation of the assessment system has referred to the guidance in the 2013 Curriculum. The assessment included the cognitive, affective, and psychomotor domains. In the 2013 Curriculum, the term was reduced to the assessment of spiritual skills, social skills, knowledge, and skills. In its implementation, History teachers used journals as an assessment instrument of students' spiritual and social attitudes, so it always appears in every lesson plan made by the teachers. While self-assessment and peer-to-peer assessment instruments are developed and applied at the end of each semester, this does not violate the rules because the assessment guidelines provide clues that the supporting instruments can be applied at least once in each semester.

This type of assessment was different from the previous curriculum known as the 2006 Curriculum or Kurikulum Tingkat Satuan Pendidikan (Education Unit Level Curriculum). The assessment system in the 2006 Curriculum was 
dominated by cognitive domains, with limited space for affective and psychomotor domains assessments that are explicitly supported by instruments. This showed that teachers are always subject to educational policy instructions, including the assessment system. In fact, although there was no specific guidance of affective and psychomotor assessments in the 2013 Curriculum, teachers should develop instruments that involve these domains.

Based on observations to the Rencana Pelaksanaan Pembelajaran (RPP) or learning activities plan document and data processing results, History teachers had implemented an authentic assessment system. However, the assessment instruments were not applicable because it was difficult to apply in the classroom. History teachers found it difficult to carry out learning along with the implementation of assessment. Therefore assessment and processing were more often conducted at home with reference to the student coding system when implementing History learning. This certainly has an impact on the lack of authenticity of the measurement data given that not all events in the class are recorded properly through the field notes.

In implementing the 2013 Curriculum policy regarding the assessment system, History teachers have tried to develop instruments in the form of journal rubrics, self-assessment instruments, peer-to-peer assessments, and observation instruments to assess students' spiritual and social skills in learning history. Meanwhile, to assess students' knowledge, history teachers more often develop written test instruments with the description of questioning techniques. The description of the matter developed was not preceded by the development of the grid, but rather developed directly from the learning objectives and indicators of competency achievement. This is not wrong but not procedural and violates the principles of instrument development. There are two types of description problems that are developed, namely the matter of objective description and non-objective description. Objective description is a question that demands an answer in the form of a definite description. This means that this question demands student answers uniformly. While non-objective description questions are types of questions whose answers are uncertain so students can answer a variety of answers that are equipped with rational evidence, and refer to the answer key.

In developing skills assessment instruments, History teachers developed various instruments such as rubrics to assess the ability to conduct research, the ability to convey historical stories based on causes and process, skills in historical debate, and other skills related to written and oral abilities in learning History. Applying authentic assessment in History subjects meant teachers had tried to do it comprehensively. Authentic assessment outputs have been utilized by History teachers to design learning programs such as remedial, enrichment, or student counseling. In addition, authentic assessment results were also used as feedback to improve the learning process in accordance with education assessment standards. 
In general, History teachers had understood the meaning of authentic assessment that assesses the readiness of students, the process, and learning outcomes as a whole. Based on the instruments developed, the teacher has implemented a whole authentic assessment both in the cognitive, affective, and psychomotor domains. The History teachers were quite capable of applying the 2013 Curriculum assessment system, although in some cases, weaknesses were still found in the application of assessment. For example, in giving a measurement score in the description problem, it has not distinguished between the weights of the objective description score with the weight of the nonobjective description score. Supposedly, between objective and non-objective description, the score weighting is distinguished.

Some of the teachers' difficulties in implementing authentic assessment are: 1) conducting an assessment together with the implementation of learning; 2) the number of assessment instruments that need to be filled requires special time; 3 ) the number of classes and students aggravate the teacher to do the assessment; 4) the more learning objectives and indicators of achievement of competence, it requires a lot of instruments as well, 5) detailed rubrics were needed to obtain authentic results; and 6) requiring special time to process the results of measurements and assessments, while teachers still need to prepare up-to-date learning tools for learning in the next day.

In processing grades, the History teacher already has sufficient ability to calculate the measurement results, then the assessment and the final decision is an evaluation activity. The teacher can systematically distinguish measurement, assessment, and evaluation activities. Measurement activities are quantification efforts using instruments that are valid and reliable regarding individual students. The assessment activities are processing the results of measurements in the form of value, both in number and letter of students individually. The criterion in question was the minimum mastery criteria that measure the ability of students to achieve learning objectives as required by core and basic competences. In the evaluation of activities, History teachers also conduct classical evaluations regarding class averages, class achievement development, and other improvements collectively.

Some of the difficulties of the history teacher in processing grades are: 1) the number of students who must be assessed because of the large number of classes; 2) assessing the results of questionnaires for students who understand that they are being assessed so that the answers are optimal and have an impact on biased data; 3) limited time to process the assessment data, and 4) the more frequent the assessment, the more the number of variables that must be accumulated.

Implementation of the assessment process and learning outcomes based on the 2013 Curriculum in the school subject was conducted using an authentic assessment approach that assesses the readiness of students, the process, and learning outcomes as a whole. The integration of the assessment of the three components will illustrate the capacity, style, and learning outcomes of students 
who are able to produce instructional effects on aspects of knowledge and the nurturing effect on aspects of attitude. It cannot be denied indeed that during the research time, the greater portion of assessment in the subject school was of knowledge. Indeed, historical knowledge must be proven by the consistency and robustness of the findings (Kreuzer, 2010). Therefore we need an in-depth assessment of the ability of students' knowledge in learning history. All historical knowledge is based on the practical needs of human life. The practical use of learning history can be examined from the educational, instructive, inspirational, and creative aspects (Mazabow, 2003). It was also said by Aisiah (2015) that learning history in secondary schools is often material-intensive and in the form of a series of historical facts.

History teachers in the school subject also saw the tendency of students to memorize history lessons rather than find the meaning behind historical facts. This means that the portion of knowledge orientation is higher among students when compared to the portion of other domains. This was also reported by Giampapa's (2005) research that, in general, students have positive perceptions of memorizing historical facts. In this case, the History teachers of the school subject always give a stimulus to students to give responses and curiosity of students to historical facts. Teachers often provide inducements in learning activities so as to encourage students to respond to the presentation of historical facts that are being learned. Syukur, Muhardjito, \& Diantoro (2014) also noted that students need to concentrate their attention to encourage curiosity. Curiosity needs to obtain a stimulus so that students will pay attention and that attention is maintained throughout the learning process.

The map of History teachers' competencies in the school subject to implement authentic assessment can be described in the following table.

Table 1: Competence of history teacher in implementing authentic assessment

\begin{tabular}{|l|l|}
\hline \multicolumn{1}{|c|}{ Aspects } & \multicolumn{1}{c|}{ Descriptions } \\
\hline $\begin{array}{l}\text { Understanding of the } 2013 \\
\text { Curriculum }\end{array}$ & $\begin{array}{l}\text { History teachers have a good understanding of the 2013 } \\
\text { curriculum of historical material, both of which include the } \\
\text { philosophy, objectives, core competencies, basic } \\
\text { competencies, learning indicators, learning objectives, } \\
\text { syllabus, lesson plans, and other learning tools as the } \\
\text { development of the 2013 curriculum. }\end{array}$ \\
\hline $\begin{array}{l}\text { Implementation of an } \\
\text { assessment system }\end{array}$ & $\begin{array}{l}\text { The assessment system conducted by the history teacher } \\
\text { follows the markings in the 2013 Curriculum which } \\
\text { concerns the evaluation of spiritual attitudes, social } \\
\text { attitudes, knowledge, and skills that are adjusted to the } \\
\text { historical material of the core and basic competencies. }\end{array}$ \\
\hline $\begin{array}{l}\text { Assessment in compulsory } \\
\text { classes and specialization in } \\
\text { history }\end{array}$ & $\begin{array}{l}\text { The History teachers in the school subject can differentiate } \\
\text { assessment in compulsory and specialization classes. } \\
\text { Assessment in the class must focus on instilling historical } \\
\text { awareness, nationalism, and the formation of national } \\
\text { character in addition to academic competence (focus on } \\
\text { historical education). As for the history specialization class, } \\
\text { the assessment focuses more on understanding and ability } \\
\text { in mastering historical facts (focusing on historical science). }\end{array}$ \\
\hline
\end{tabular}




\begin{tabular}{|l|l|}
\hline \multicolumn{1}{|c|}{ Aspects } & \multicolumn{1}{c|}{ Descriptions } \\
\hline Instrument development & $\begin{array}{l}\text { History teachers are quite capable in developing authentic } \\
\text { assessment instruments as evidenced by assessment } \\
\text { instruments developed in accordance with the demands of } \\
\text { core competencies and basic competencies. The teacher is } \\
\text { also able to formulate indicators of achievement and } \\
\text { learning objectives, and the instruments developed refer to } \\
\text { learning goals }\end{array}$ \\
\hline Implementation of & $\begin{array}{l}\text { History teachers are quite capable in the implementation of } \\
\text { authentic assessments } \\
\text { instruments developed and their application in assessment. } \\
\text { The instrument developed was quite simple and applicable } \\
\text { so that the results were authentic according to students' } \\
\text { ability levels, although there were some difficulties in their } \\
\text { implementation. }\end{array}$ \\
\hline Value processing & $\begin{array}{l}\text { The ability of history teachers in processing measurement } \\
\text { results is quite good as evidenced by the analysis of all } \\
\text { measurement results for assessment and evaluation, } \\
\text { although there are some difficulties found in their } \\
\text { implementation. }\end{array}$ \\
\hline
\end{tabular}

Source: Primary data.

The authentic assessment carried out in the school subject can map student learning outcomes in an authentic and comprehensive manner, which is certainly related to cognitive, affective, and psychomotor domains. Authentic assessment results are used by teachers to plan remedial learning programs, enrichments, or counseling services. In addition, authentic assessment results are used as material to improve the learning process in accordance with Education Assessment Standards. Evaluation of the learning process is carried out during the learning process by using tools: observation sheets, peer questionnaires, recordings, anecdotal notes, and reflections. Evaluation of learning outcomes is carried out during the learning process and at the end of the lesson, a unit using methods and tools: oral / deed tests and written tests. Final evaluation results are obtained from a combination of process evaluation and evaluation of learning outcomes.

A good assessment system should be able to help students achieve their learning goals. Although the teaching and learning process cannot be entirely centered on students as in open education, what needs to be observed is that in essence, students must learn and develop themselves so that the assessment system applied must be based on students' circumstances. Thus, the teaching and learning process needs to be oriented to the needs and abilities of students. The activities carried out in the teaching and learning process must be able to provide a pleasant and useful learning experience for students. Teachers should provide a variety of learning atmosphere that is adequate for the material presented and adapt it to the abilities and characteristics of students as subjects. Likewise, the assessment system must be in accordance with the principles of authentic assessment, which in many findings could lead to significant learning improvement (Nicol \& Macfarlane-Dick, 2006; Andersson \& Palm, 2017, and Black \& Wiliam, 2018). 
In this research, 2013 Curriculum adheres to several principles, namely: (1) learning conducted by teachers (taught curriculum) in the form of processes developed in the form of learning activities in schools, classrooms, and the community; and (2) students' direct learning experiences (learned curriculum) according to the background, characteristics, and initial abilities of students. Student's direct learning experiences become learning outcomes for themselves, while the learning outcomes of all students become the results of the curriculum. Core competencies are designed along with the increasing age of students in certain classes. Through core competencies, vertical integration of various basic competencies in different classes can be maintained. The approach used to integrate basic competencies from various subjects is intra-disciplinary, interdisciplinary, multi-disciplinary, and trans-disciplinary.

Intra-disciplinary integration has been used in various ways at all levels of education and is the main key to the progress of the school curriculum at every level of education (Jones, 2009). Intra-disciplinary integration is carried out by integrating the dimensions of attitudes, knowledge, and skills into a unified whole in each subject. Interdisciplinary integration is carried out by combining the basic competencies of several subjects so that they are related to one another so that they can strengthen one another, avoid overlapping, and maintain the harmony of learning. Interdisciplinary integration allows students to see different perspectives, work in groups, and make a synthesis of scientific disciplines as the ultimate goal of learning (Jones, 2009). Multi-disciplinary integration is carried out without combining the basic competencies of each subject so that each subject still has its own basic competence. Trans-disciplinary integration is carried out by linking the various existing subjects with the problems encountered around them so that learning becomes contextual. Compulsory subjects group is part of general education, namely education for all citizens aimed at providing knowledge about the nation, attitudes as a nation, and important abilities to develop the personal lives of students, society, and nation. Although it has many advantages such as broadening student understanding, increasing student achievement and improving students' skills in communication in all disciplines, it also has weaknesses, such as the confusion of integration and time-consuming curriculum preparation (Jones, 2009).

The need for authentic assessment instruments becomes an important requirement because the assessment is one of the factors that can be used to evaluate the learning process. As explained by Law of Republic of Indonesia No. 20 of 2003 concerning the National Education System that the evaluation of student learning outcomes is carried out by teachers to monitor the process, progress, and improvement of student learning outcomes on an ongoing basis. Good assessment instruments need to pay attention to the learning flow of students. Assessment instruments must be able to reflect the competence of students and can be used as an effort to perfect learning.

In accordance with the 2013 Curriculum concept, the terms academic, social, and personality are expressed more in attitude, knowledge, and skills competencies. 
As explained by the Ministry of Education and Culture, "authentic assessment is a significant measurement of student learning outcomes for the realm of the attitude of knowledge and skills." A similar concept also put forward by Gulikers, Bastiaens, \& Kirschner (2004) that "authentic assessment requires students to use the same competencies, or combinations of knowledge, skills, and attitudes, that they need to apply in the criterion situation in professional life." The purpose of such an opinion is that authentic assessments assess some of the students' competencies or a combination of knowledge, skills, and attitudes that they can apply in professional life.

An authentic assessment has strong relevance to the scientific approach to learning in accordance with the demands of the 2013 Curriculum. Because, this kind of assessment is able to illustrate the improvement in student learning outcomes, both in the framework of observing, reasoning, trying, building networks, etc. The authentic assessment tends to focus on complex or contextual tasks, allowing students to show their competence in more authentic settings. Therefore, authentic assessment is very relevant to integrate thematic approaches in teaching, especially at the elementary school level or for appropriate subjects. Other words from the authentic assessment are performance appraisal, portfolio, and project appraisal. An authentic assessment is sometimes called responsive assessment, a very popular method for assessing the learning processes and learning outcomes of students who have special characteristics, ranging from those who have certain disorders, have special talents and interests, to geniuses. Authentic assessment can also be applied in certain fields of science, such as art or science, in general, with its main orientation on the process of learning outcomes.

Every activity, both educational and non-educational, should be followed by assessment and evaluation activities. The assessment is carried out aimed at assessing whether a program is carried out in accordance with planning and achieving results as expected or not. Based on the results of the evaluation, things that have been achieved can be known, whether a program can meet predetermined criteria. After that, a decision is made on whether the program is continued, revised, terminated, or reformulated so that new objectives, targets, and alternatives can be found that is completely different from the previous format. In order to arrange a better program, the results of the previous program evaluation can be used as the main reference. In the program itself, the assessment system is one of the components that must be present in learning activities.

History teachers of the school subject are able to develop instruments, carry out assessments, and process the assessment results. However, there are still some weaknesses in the implementation. For example, the instrument is the same even though the BC is different, the assessment is not directly at the time of learning, and the processing of values requires a special time. In the meantime, in terms of the targets to be achieved, the evaluation of the education sector can be divided into two, namely evaluations that are macro and micro in nature. Macro evaluation targets the planned education program, and the aim is to improve the 
field of education. Micro-evaluation is often used at the classroom level. The target of micro-evaluation is the learning program in the classroom and the teacher in charge. The teacher has the responsibility to compile and implement the learning program, while the school has the responsibility to evaluate the implementation of learning so that the main learning objectives can be achieved.

In the meantime, one important factor for improving the quality of education is through learning programs, and evaluation is one of the important factors of learning programs. The evaluation must be an important part and carried out continuously to improve the quality of education. In addition to evaluations are useful for school leaders as an effort to photograph the education system that is their responsibility, evaluation can also foster student interest and motivation to study harder, and also to encourage teachers to further improve their performance in working as professional educators. Thus, evaluation is not only focused on the assessment of learning outcomes but also needs to be based on an assessment of the input and the learning process itself. In this conception, the optimization of the evaluation system has two meanings, namely an evaluation system that provides optimal information, and the benefits achieved from the evaluation.

The main benefit of conducting an educational assessment is to improve the quality of learning. Therefore, the implementation of an assessment of the learning process is expected to improve the quality of subsequent learning, which will certainly improve the quality of education in general. Thus, the authentic assessment system in teaching programs is an important part of a learning program, so that its effectiveness and efficiency must exist in learning activities. The substance of authentic assessment objectives is to measure students' competencies. Student learning is directed directly at complex competency assessments, concluding that student competencies are more valid than during learning, and competencies that are assessed are not limited by the situation of a test.

Conceptual and implementation of authentic assessment are different from traditional assessment systems (Lombardi, 2008). The traditional assessment, for example, uses multiple-choice test forms for evaluation while authentic assessment integrates written and performance tests. The History teachers of the subject school basically had applied the principles of authentic assessment, so it can be stated that the history teacher has competency in the implementation of authentic assessment. The authentic assessment also emphasizes problems in real life in the community Gulikers, Bastiaens, \& Kirschner, 2004 and Jaedun, Hariyanto, \& Nuryadin, 2014). In addition, authentic learning can also generate authentic contexts that can reflect the way knowledge is used in real life. It will produce authentic activities that support collaborative knowledge. Students can articulate to allow hidden knowledge to be explicit. Thus, teachers can coach and produce authentic learning assessments (Herrington \& Oliver, 2000 and Scholtz, 2007). 
In research conducted by Azim and Khan (2012), analysis of data obtained from interviews, observations, and student work shows that authentic assessment can also develop higher-order thinking skills. Although authentic assessments are complex and take a long process, the evidence presented in their research emphasizes that authentic assessment is important for improving education in assessment where the assessment itself is not just a process that facilitates student learning, but also a tool used to evaluate the teaching and learning process. During the process of authentic assessment, students learn actively and take responsibility for their own learning processes. On the other hand, the teacher's role is only to facilitate the learning process.

Jaedun, Hariyanto, and Nuryadin (2014) showed that the readiness of teachers in designing, planning, and implementing learning activities and assessments in the implementation of the 2013 Curriculum was still very low. The ability of teachers to prepare complete and correct lesson plans must still be improved. The majority of teachers do not understand the principles and applications of learning models that use the methods in the 2013 Curriculum. Although the teacher has arranged learning activities from the beginning, core learning, and final learning, the realization of the activities is still not in line with its provisions. Most teachers also have not applied communication and information technology (ICT) in teaching and learning activities. This is also supported by the fact that even though the teacher has developed a learning assessment instrument, the assignments given to students are known to have not played an authentic task.

An authentic assessment, as explained above, is important for teachers to pay attention to in order to encourage students' learning motivation. In addition, History teachers of the school subject also always try to perfect the learning process as feedback from measuring student competency. In accordance with the opinion of Nicol \& Macfarlane-Dick (2006) that there are seven principles of giving good feedback, namely: 1) helping to clarify the good performance, 2) facilitating the development of self-assessment or reflection in learning, 3) providing quality information to students about students learning outcome, 4) encouraging teachers and colleagues to dialogue about learning, 5) encouraging positive motivation and self-esteem, 6) providing opportunities to overcome the gap between existing and desired performance, and 7) providing information to educators that can be used to help to improve the learning conditions.

\section{Conclusion}

The research results show that: 1) the reality of the assessment system follows the guidelines in the 2013 Curriculum which concern the assessment of spiritual attitudes, social attitudes, knowledge, and skills; 2) History teachers are quite capable in developing authentic assessment instruments proven by assessment instruments developed in accordance with the demands of core competencies and basic competencies; 3) the ability of history teachers in implementing authentic assessment is quite good where there is a match between the instruments developed and its application in assessment, and 4) the ability of the 
history teacher in processing measurement results is quite well proven by analyzing all measurement results for assessment and evaluation. The conclusion of this research shows that the History teachers of the subject school are able to apply authentic assessment that refers to the demands of the 2013 Curriculum.

Based on the above conclusions, the following suggestions can be formulated: the principal needs to conduct periodic evaluations and supervision to ensure the professionalism of teachers in the implementation of the 2013 Curriculum, not least on the authentic assessment system. In teaching and learning activities, teachers must try to develop instruments in accordance with the core, and basic competencies discussed and to implement authentic assessment systems in a sustainable manner. Authentic assessment efforts that include spiritual, social attitude, knowledge, and skills need to be continuously integrated comprehensively in realizing quality schools, which are the key to school success in achieving the vision and mission of the school. In realizing the results of the assessment in accordance with field conditions, it is necessary to continue to develop a comprehensive assessment system with instruments that are more practical, valid, reliable, and sensitive to have good quality.

\section{References}

Admiraal, W., Janssen, T., Huizenga, J., Kranenburg, F., Taconis, R., \& Corda, A. (2014). E-assessment of student-teachers' competence as new teachers. TOJET: The Turkish Online Journal of Educational Technology, 13(4), 21-29. http://www.tojet.net/abstracts/v13i4/1343_abstract.htm

Aisiah. (2015). Model asesmen diri untuk kesadaran sejarah (momendikejar) di perguruan tinggi (Khusus untuk mahasiswa calon guru sejarah) [Self-assessment model for history cognition in higher education (Case study among students of history teaching)]. Ph.D. Dissertation. Yogyakarta: Program Pascasarjana Universitas Negeri Yogyakarta. Retrieved from https://eprints.uny.ac.id/35039/

Aman. (2015). Kesiapan guru sejarah SMA Islam 1 Gamping Sleman dalam implementasi Kurikulum 2013 [SMA Islam 1 Gamping Sleman history teacher's readiness in implementing Curricula 2013]. Istoria Jurnal Pendidikan \& Ilmu Sejarah, 11(2), 14-27. https://doi.org/10.21831/istoria.v11i2.7557

Andersson, C. \& Palm, T. (2017). Characteristics of improved formative assessment $\begin{array}{llll}\text { practice. } & \text { Education } & \text { Inquiry, } & \text { 8(2), }\end{array}$ https://doi.org/10.1080/20004508.2016.1275185

Archbald, D.A. \& Newmann, F.M. (1988). Beyond standardized testing: Assessing authentic academic achievement in the secondary school. Reston, VA, National Association of Secondary School Principals.

Ayati, M. H., Pourabbasi, A., Namazi, N., Zargaran, A., Kheiry, Z., Kazemi, A. H., \& Larijani, B. (2019). The necessity for integrating traditional, complementary, and alternative medicine into medical education curricula in Iran. Journal of Integrative Medicine, 17(4), 296-301. https://doi.org/10.1016/j.joim.2019.04.005

Azim, S., \& Khan, M. (2012). Authentic assessment: An instructional tool to enhance students learning. Academic Research International, 2(3), 314-320. Retrieved from http://ecommons.aku.edu/pakistan_ied_pdcc/11

Barth, R. S. (1981). The principal as staff developer. Journal of Education, 163(2), 144-162. https://doi.org/10.1177/002205748116300207 
Berkvens, J., Van den Akker, J., \& Brugman, M. (eds.) (2014). Addressing the quality challenge: Reflections on the post-2015 UNESCO education agenda. Enschede, The Netherlands: Netherlands National Commission for United Nations Educational, Scientific and Cultural Organization (UNESCO).

Black, P., \& Wiliam, D. (2018). Classroom assessment and pedagogy. Assessment in Education: Principles, Policy \& Practice, 25(6), 551-575. https://doi.org/10.1080/0969594X.2018.1441807

Brown, A. H., \& Green, T. D. (2016). The essentials of instructional design: Connecting fundamental principles with process and practice, Third edition. New York: Routledge.

Celik, S. (2011). Characteristics and Competencies for Teacher Educators: Addressing the Need for Improved Professional Standards in Turkey. Australian Journal of Teacher Education, 36(4), 264-278. https://.doi.org/10.14221/ajte.2011v36n4.3

Chowthi-Williams, A. (2018). Evaluation of how a real time pre-registration health care curricula was managed through the application of a newly designed Change Management Model: A qualitative case study. Nurse Education Today, 61, 242-248. https://doi.org/10.1016/j.nedt.2017.12.004

DuFour, R., \& Barkey, T. (2005). The principal as staff developer. Journal of Staff Development, 16(4), 2-6. Retrieved from https:/ / eric.ed.gov/?id=EJ522301

Falchikov, N., \& Thompson, K. (2008). Assessment: What drives innovation? Journal of University Teaching and Learning Practice, 5(1), 49-60. Retrieved from https://ro.uow.edu.au/jutlp/vol5/iss1/5/

Forsyth, H., \& Evans, J. (2019). Authentic assessment for a more inclusive history. Higher Education Research \& Development, 38(4), 748-761. https://doi.org/10.1080/07294360.2019.1581140

Frey, B. B., \& Allen, J. P. (2012). Defining authentic classroom assessment. Practical Assessment, Research \& Evaluation, 17(2), 215-232. Retrieved from https:/ / pareonline.net/getvn.asp? $\mathrm{v}=17 \& \mathrm{n}=2$

Giampapa, R. M. (2005). Constructing historical conciousness in Greece: Cultural syncretisme in the context of European unification. Ph.D. Dissertation. Ohio: Ohio University.

Gronlund, N. E. \& Linn, R. L. (1990). Measurement and evaluation in teaching (6th ed). New York: Collier Macmillan Publishers.

Gulikers, J. T. M., Bastiaens, T. J., \& Kirschner, P. A. (2004). A five-dimensional framework for authentic assessment. Educational Technology Research and Development, 52, 67-86. https://doi.org/10.1007/BF02504676

Halek, D. H. (2019). Kurikulum 2013 dalam perspektif filosofi [Curriculum 2013 in philosophical perspective]. Jurnal Georafflesia: Artikel Ilmiah Pendidikan Geografi, 3(2), 1-10. https://doi.org/10.32663/georaf.v3i2.567.

Hasan, S. H. (2008). Evaluasi kurikulum [Curriculum evaluation]. Bandung: PT Remaja Rosdakarya.

Hidayani, M. (2017). Pembelajaran tematik dalam Kurikulum 2013 [Thematic learning in Curriculum 2013]. At-Ta'lim : Media Informasi Pendidikan Islam, 15(1), 150-165. http:/ /dx.doi.org/10.29300/attalim.v15i1.292

Huitt, W., Hummel, J., \& Kaeck, D. (2001). Assessment, measurement, evaluation, and research. Educational Psychology Interactive. Valdosta, GA: Valdosta State University. Retrieved http://www.edpsycinteractive.org/topics/intro/sciknow.html

Jaedun, A., Hariyanto, V. L., \& Nuryadin, E. R. (2014). An evaluation of the implementation of Curriculum 2013 at the building construction department of vocational high schools in Yogyakarta. Journal of Education, 7(1), 14-22. Retrieved from https://journal.uny.ac.id/index.php/joe/article/view/5757

Jones, C. (2009). Interdisciplinary approach: Advantages, disadvantages, and the future benefits of interdisciplinary studies. ESSAI, 7(1), 26. Retrieved from http://dc.cod.edu/essai/vol7/iss1/26 
Kardiana, I. G., Marhaeni, A. A. I. N., \& Ratminingsih, N. M. (2019). A discrepancy analysis of authentic assessment implementation in EFL classroom of senior high school in Badung based on Curriculum 2013. Jurnal Pendidikan Bahasa Inggris Indonesia, 7(1), 1-9. https://doi.org/10.23887/jpbi.v7i1.2716

Khoza, S. B. (2016). Can curriculum managers' reflections produce new strategies through Moodlei visions and resources? South African Journal of Education, 36(4), 119-137. http://dx.doi.org/10.15700/saje.v36n4a1317

Kreuzer, M. (2010). Historical knowledge and quantitative analysis: The case of the origins of proportional representation. American Political Science Review, 104(2), 369-392. https:/ / doi.org/10.1017/S0003055410000122

Kurniawati, A., \& Sukardiyono. (2018). The development of authentic assessment instrument to measure science process skill and achievement based on students' performance. Jurnal Penelitian \& Pengembangan Pendidikan Fisika, 4(2), 65-74. https://doi.org/10.21009/1.04203

Leigh, A. (2010). Estimating teacher effectiveness from two-year changes in students' test scores. Economics of Education Review, 29(3), 480-488. https://doi.org/10.1016/j.econedurev.2009.10.010

Lombardi, M. M. (2008). Making the grade: The role of assesment in authentic learning. Educase Learning Initiave Paper 1. Retrieved from https://library.educause.edu/resources/2008/1/making-the-grade-the-role-ofassessment-in-authentic-learning

Mardapi, D. (2013). Pengembangan instrumen evaluasi pembelajaran [Development of educational evaluation instruments]. Yogyakarta: UNY Press.

Mazabow, G. (2003). The development of hostorical conciousness in the teaching of history in South Africa schools (Ph.D.'s Dissertation). Pretoria: University of South Africa. Retrieved from http://hdl.handle.net/10500/1170

Mulyana, T. (2012). Pengembangan bahan ajar melalui desain penelitian [Development of teaching materials through research design]. Infinity, 12(2), 85-101. https:// doi.org/10.22460/infinity.v1i2.p126-137

Newmann, F. M. (1997). Authentic assessment in social studies: Standards and examples. In G.D. Phye (Ed.), Handbook of classroom assessment: Learning, adjustment and achievement. San Diego, Ca: Academic Press.

Nicol, D. J., \& Macfarlane-Dick, D. (2006). Formative assessment and self-regulated learning: A model and seven principles of good feedback practice. Studies in Higher Education, 31(2), 1999-2018. https:/ / doi.org/10.1080/03075070600572090

Nurhayati, E., Jayusman, \& Ahmad, T. A. (2018). Implementasi penilaian autentik dalam pembelajaran sejarah di SMA Negeri 1 Semarang [Implementation of authentic assessment in History subject in SMA Negeri 1 Semarang]. Indonesian Journal of History Education, 6(1), 21-30. Retrieved from https://journal.unnes.ac.id/sju/index.php/ijhe/article/view/27334

Ornstein, A. C., \& Hunkins, F. P. (2009). Curriculum: Foundations, principles, and issues, Fifth edition. Singapore: Pearson.

Palm, T. (2008). Performance assessment and authentic assessment: A conceptual analysis of the literature. Practical Assessment, Research \& Evaluation, 13(4), 129-142. Retrieved from https:/ / pareonline.net/getvn.asp? $\mathrm{v}=13 \& \mathrm{n}=4 \% 20$

Phillips, P. (2008). Professional development as a critical component of continuing teacher quality. Australian Journal of Teacher Education, 33(1), 37-45. http://doi.org/10.14221/ajte.2008v33n1.3

Pinar, W. F., \& Irwin, R. L. (eds). (2005). Curriculum in a new key: The collected works of Ted T. Aoki. New Jersey: Lawrence Erlbaum Associates.

Prihantoro, C. R. (2015). The perspective of curriculum in Indonesia on environmental education. International Journal of Research Studies in Education, 4(1), 77-83. https://doi.org/10.5861/ijrse.2014.915 
Puckett, M. B., \& Black, J. K. (2000). Authentic assessment of the young child: Celebrating developing and learning (2nd ed.). New Jersey: Prentice-Hall, Inc.

Rahayu, T., Maftukhin, A., \& Sriyono. (2013). Pengembangan authentic assessment untuk mengukur sikap, proses, dan penerapan dalam pembelajaran Fisika pada siswa SMA Negeri 9 Purworejo tahun pelajaran 2012/ 2013 [Development of authentic assessment to measure attitude, process, and implementation of Physics subject among students in SMA Negeri 9 Purworejo academic year 2012/ 2013]. RADIASI: Jurnal Berkala Pendidikan Fisika, 3(1), 54-57. Retrieved from http://ejournal.umpwr.ac.id/index.php/radiasi/article/view/657

Rennert-Ariev, P. (2005). A theoretical model for the authentic assessment of teaching. Practical Assessment, Research \& Evaluation, 10(2), 1-11. Retrieved from https:// pareonline.net/getvn.asp? $\mathrm{v}=10 \& \mathrm{n}=2$

Retnawati, H., Hadi, S., \& Nugraha, A. C. (2016). Vocational high school teachers' difficulties in implementing the assessment in Curriculum 2013 in Yogyakarta Province of Indonesia. International Journal of Instruction, 9(1), 33-48. https://doi.org/10.12973/iji.2016.914a

Reynold, C. R., Livingstone, R. B., \& Wilson, V. (2010). Measuremet and assesment in education. New York: Pearson.

Richard, J. C. (2001). Curriculum development in language teaching. Cambridge: Cambridge University Press.

Richards, J., \& Lockhart, C. (1996). Reflective teaching in second language classrooms. New York: Cambridge University Press.

Rourke, A. J., \& Coleman, K. S. (2011). Authentic assessment in e-learning: Reflective and collaborative writing in the arts. Proceedings Ascilite 2011, Hobart: Concise Paper. 1089-1095.

Retrieved

from

http://www.ascilite.org/conferences/hobart11/downloads/papers/Rourkeconcise.pdf

Rukmini, D. M., Marhaeni, A. A. I. N., \& Artini, L. P. (2017). Discrepancy analysis of authentic assessment implementation in EFL classroom based on Curriculum 2013 in SMAN 1 Kuta. Jurnal Pendidikan Bahasa Inggris Indonesia, 5(3). https://doi.org/10.23887/jpbi.v5i3.2522

Rusman. (2015). Curriculum implementation at elementary schools: A study on "best practices" done by elementary school teachers in planning, implementing, and evaluating the curriculum. Journal of Education and Practice, 6(21), 106-112. Retrieved from https://iiste.org/Journals/index.php/JEP/article/view/24219

Scholtz, A. (2007). An analysis of the impact of an authentic assessment strategy on student performance in a technology-mediated constructivist classroom: A study revisited. International Journal of Education and Development Using Information and Communication Technology, 3(4), 42-53. Retrieved from https://www.learntechlib.org/p/42221/

Suastini, N. L. P., Marhaeni, A.A.I.N., \& Artini, L.P. (2018). Discrepancy analysis of authentic assessment implementation based on Curriculum 2013 in EFL classroom at SMA Negeri 1 Kuta Utara, Badung. Jurnal Pendidikan Bahasa Inggris Indonesia, 6(2), 1-10. https://doi.org/10.23887/jpbi.v6i2.2713

Sugiyono. (2014). Metodologi penelitian pendidikan: Pendekatan kualitatif, kuantitatif, dan R E $D$ [Research methods in education: Qualitative, quantitative, and $R \& D$ approaches]. Bandung: Alfabeta.

Herrington, J., \& Oliver, R. (2000). An instructional design framework for authentic learning environments. Educational Technology Research and Development, 48(3), 2348. Retrieved from https://www.learntechlib.org/p/90687/

Surya, A., \& Aman. (2016). Developing formative authentic assessment instruments based on learning trajectory for the fourth grade students of elementary schools. 
Journal Research and Evaluation in Education, 2(1), 13-24. https://doi.org/10.21831/reid.v2i1.6540

Syukur, I. A., Muhardjito, \& Diantoro, M. (2014). Pengaruh model pembelajaran teams games tournament termodivikasi berbasis outbound terhadap prestasi belajar Fisika ditinjau dari motivasi belajar [Impact of teams games tournament modified based on outbound on Physics academic achievement as viewed from learning motivation]. Jurnal Pendidikan dan Kebudayaan, 20(3), 310-327. http:/ / doi.org/10.24832\%2Fjpnk.v20i3.146

Vu, T. T., \& Dall'Alba, G. (2014). Authentic Assessment for Student Learning: An ontological conceptualization. Educational Philosophy and Theory, 46(7), 778-791. https://doi.org/10.1080/00131857.2013.795110. 